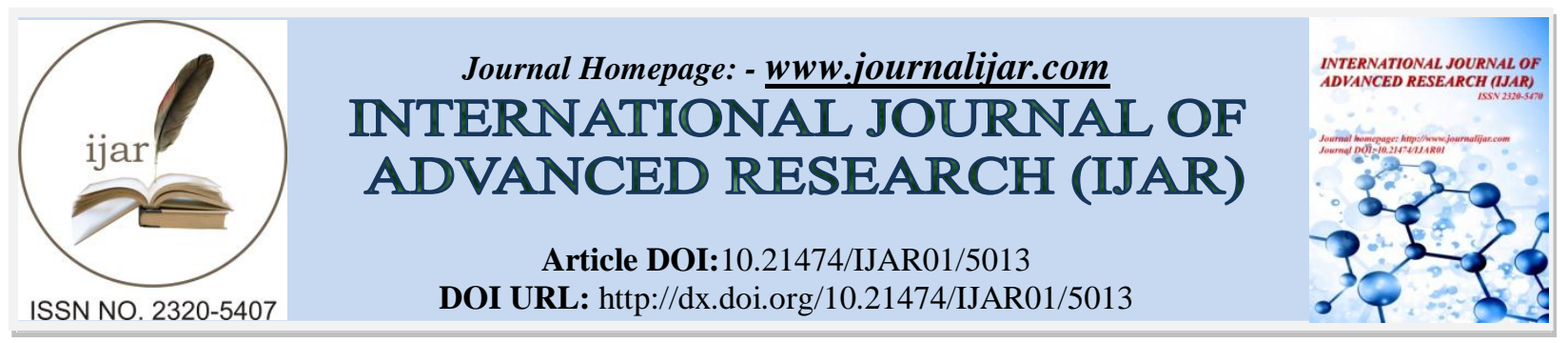

RESEARCH ARTICLE

\title{
MUD CRAB SCYLLA SERRATA (FORSKAL) AS CARRIER OF WHITE SPOT SYNDROME VIRUS (WSSV) IN CORINGA MANGROVES, ANDHRA PRADESH.
}

\author{
Vijaya Bharathi. T', Myla S. Chakravarty ${ }^{2}$ and P. R. C. Ganesh ${ }^{2}$. \\ 1. State Institute of Fisheries Technology, Jagannaickpur, Kakinda \\ 2. Andhra University, Department of Marine Living Resources, College of Science and Technology, \\ Visakhapatnam.
}

\section{Manuscript Info}

\section{Manuscript History}

Received: 28 May 2017

Final Accepted: 30 June 2017

Published: July 2017

Key words:-

White spot syndrome virus, Coringa mangroves, mud crab, Scylla serrata

\section{Abstract}

The prevalence of white spot syndrome virus in wild mud crabs in Coringa mangroves was studied at molecular level. 357 crab samples were tested through PCR at three sampling stations-Kakinada Bay, Coringa and Gaderu. Of them, 58 were positive (16\%) and 299 negative in the first step PCR whereas 132 were positive (37\%) and 225 were negative in the nested PCR. At Kakinada Bay, there was $16.4 \%$ positivity in first step PCR and $36 \%$ in the second step, whereas in Coringa creek it was $14.4 \%$ and $37.3 \%$ in the first and second step respectively. In Gaderu creek the crabs were $17.1 \%$ positive in the first step PCR and $37.6 \%$ in the second step. $31.8 \%$ were positive to the virus in 2007 and in 2008 it was $36.09 \%$. WSSV prevalence was more in smaller size group $(0-4.0 \mathrm{~cm})$ i.e., about $52 \%$ in 2007 and 2008 and decreased with increasing size groups $(36.6 \%$ in 2007 and $31.7 \%$ in 2008 in the size group $(5.0-8.0 \mathrm{~cm})$. In $9.0-13 \mathrm{~cm}$ size class it was $29.69 \%$ in 2007 and $36.09 \%$ in 2008

Copy Right, IJAR, 2017,. All rights reserved

\section{Introduction:-}

Mass mortality of commercially important shrimps has occurred in many Asian countries due to disease out breaks (Kim et al., 1998) and viral pathogens cause major damage leading to serious economic loss (Flegel, 2001). In nature, a high percentage of apparently normal and healthy animals harbour potential pathogens without evidence of clinical signs or over disease (Wedemeyer, 1970). Aquatic organisms particularly fisheries are generally affected by endemic, epizootic and infectious diseases and diseases caused by microorganisms are more devastating. White Spot Syndrome Virus is known to affect the tissues of ectodermal and mesodermal origin like cuticle, gill, gut, lymphoid organs, antennal gland, hematopoietic tissues, connective tissue, ovary and the ventral nerve cord (Wongteerasupaya et al., 1995, Wang et al.,1999). This disease affects shrimps of all ages \& sizes, also present in a wide range of hosts- penaeids, crabs, lobsters and other crustaceans like copepods and amphipods (OIE, 2003). WSSV infection is characterized by reduction in food intake and a loose cuticle with white spots on the inner surface (Takahashi et al., 1994).

Decapod crustaceans like crabs play an important role as 'carrier' of WSSV in natural environment. Several methods are available for the detection of the white spot disease virus, including PCR (Kim et al., 1998; Nunan et al., 1998; Peng et al., 1998), Dot blot hybridization (Wongteerasupaya et al., 1996; Sahul Hameed et al., 1998) and ELISA (Sahul Hameed et al., 1998). Molecular primers based on the probes have been developed for WSSV 
detection by Polymerase Chain Reaction (Chang et al., 1996, Lo et al., 1996; Van Hulten et al., 2000; Hossain et al., 2001). These molecular techniques are highly specific and have a high degree of sensitivity. Nested PCR has been reported to increase sensitivity of detection by $10^{3}-10^{4}$ times (Lo et al., 1996) and sensitivity increases as the amplicon size decreases (Hossain et al., 2004).

In the present study, molecular epidemiology of White Spot Syndrome Virus (WSSV) in the mangrove crab, Scylla serrata (Forskal) has been taken up to assess the prevalence of the virus in crabs, which serve as carriers of the virus.

\section{Material and methods:-}

Crabs were collected from three stations- Kakinada Bay (Station I, $16^{0} 54$ '20.59' 'N, 82 ${ }^{0} 15^{\prime} 01.52^{\prime}$ 'E), Coringa creek (Station II, $16^{0} 52^{\prime} 31.88^{\prime}{ }^{\prime} \mathrm{N}, 82^{0} 16^{\prime} 11.71^{\prime}$ 'E) and Gaderu creek (Station III, $16^{0} 51^{\prime} 07.02{ }^{\prime}{ }^{\prime} \mathrm{N}, 82^{0} 18^{\prime} 43.51$ ' $\mathrm{E}$ ) in the Coringa mangrove forest area of Andhra Pradesh, India (Fig.1) where shrimp culture was carried out in the vicinity. A total of $357 \mathrm{crab}$ samples were collected from three field stations and were categorized into size groups of 0-4 cm, $5-8 \mathrm{~cm}$ and $9-13 \mathrm{~cm}$. The prevalence of WSSV was assayed every month from the gills and was grouped into $1^{\text {st }}$ half of the year and $2^{\text {nd }}$ half in 2007 and 2008. Polymerase Chain Reaction (PCR) technique was employed to detect the presence of virus in the crabs. Test kits for conducting the PCR were procured from M/S Mangalore Biotech Ltd, Mangalore, Karnataka, India and were used for DNA extraction, DNA amplification and DNA detection following the methods of Sambrook and Russel (2001).

\section{Extraction of DNA:-}

Crab samples were brought to the laboratory in live condition. In the laboratory, the gills were dissected out and collected in sterile plastic sachets. Digestion Buffer (Guanidium Chloride) was added (800 $\mu 1)$ to the plastic sachet containing the gills of the live crabs and the material was macerated in the sachet and incubated at room temperature for about 10-15 minutes. The homogenate was transferred to $1.5 \mathrm{ml}$ micro centrifuge tube and centrifuged (Remi, C24) at $4000 \mathrm{rpm}$ for 5 minutes. $150 \mu \mathrm{l}$ of supernatant was transferred to a fresh micro centrifuge tube and to it DNA precipitation Buffer (Absolute Ethyl Alcohol) was added $(450 \mu \mathrm{l})$. The tube was centrifuged at 10,000-12,000 rpm for 10 minutes at $4^{0} \mathrm{C}$. Then the supernatant was discarded. DNA washing Buffer (70\% Ethyl Alcohol) (450 $\left.\mu 1\right)$ was added and centrifuged at 10,000-12,000 rpm for 5 minutes at $4^{0} \mathrm{C}$. The supernatant was then discarded and the pellet was dried at room temperature. After drying the pellet, it was dissolved in $100 \mu$ l of double distilled water, which will contain the DNA of White Spot Syndrome Virus, if present, in the sample.

\section{DNA Amplification:-}

$2 \mu 1$ of template DNA was taken into the master mix tubes (reagent mixture tubes that contain amplification buffer, dNTPs, amplification grade water, $\mathrm{Mg}^{++}$and Taq polymerase). Nested PCR amplification was carried out in a Thermocycler (Eppendorf) for WSSV following a temperature profile, with an initial denaturation for 5 min. at $94^{0} \mathrm{C}$ followed by 30 cycles at $94^{\circ} \mathrm{C}$ for 30 seconds; $55^{\circ} \mathrm{C}$ for 30 seconds; $72^{\circ} \mathrm{C}$ for 30 seconds and a final extension at $72^{\circ} \mathrm{C}$ for $5 \mathrm{~min}$. PCR was carried out using species-specific primers namely $486 \mathrm{bp}$ fragment in first step and $310 \mathrm{bp}$ in the second step.

Termocycler was programmed as: I step- initial denaturation at $94^{0} \mathrm{C}$ for 5 min followed by each cycle of denaturation at $94^{\circ} \mathrm{C}$ for $30 \mathrm{sec}$, annealing at $42^{\circ} \mathrm{C}$ for $30 \mathrm{sec}$, extension at $72^{\circ} \mathrm{C}$ for $40 \mathrm{sec}$ and a final delay at $72^{\circ} \mathrm{C}$ for $7 \mathrm{~min}$, the same conditions were followed in the second step also. In every batch of reaction, a positive control and negative control was included.

\section{DNA Detection:-}

PCR products, after DNA amplification in the thermocycler were separated by agarose gel (1\%) containing $0.5 \mu \mathrm{g}$ per $\mathrm{ml}$ ethidium bromide and observed in a DNA transilluminator (Genei). Depending on the size of the electrophoresis tank, the quantity of agarose gel (1\%) required was prepared. The agarose in 1x TAE (Tris Acetate EDTA) buffer was heated till the agarose was completely melted and cooled to room temperature. Before pouring the gel on to the already set gel platform, 5 - $\mu$ l ethidium bromide per $100 \mathrm{ml}$ was added.

After the gel was set, it was placed in the electrophoresis chamber. $20 \mu \mathrm{l}$ of product was taken after DNA amplification and it was mixed with $4-\mu 1$ gel loading buffer (Bromophenol Blue) and loaded the gel. 8- $\mu 1$ molecular weight marker (100 bp DNA size marker) was loaded in a separate lane of the gel. The gel was run at 80 volts for 10 
minutes and then at 120 volt till the tracking dye moves about $2 \mathrm{~cm}$ from the edge of gel. Finally the gel was viewed under the UV transilluminator and the results were documented with a UV documentation unit (Uvidoc).

\section{Results:-}

A total of 357 crab samples were tested for WSSV with PCR in the study area. Out of these, 58 are positive (16\%) and 299 are negative in the first step PCR whereas 132 are positive (37\%) and 225 are negative in the nested PCR (Fig.2).

\section{WSSV Prevalence:-}

In the $1^{\text {st }}$ half of the year (2007) at Kakinada bay, the incidence of WSSV was $10.71 \%$ in the first step and $32.14 \%$ in the second step. In the $2^{\text {nd }}$ half $22.22 \%$ were positive and $44.44 \%$ in the second step. In Coringa creek, the incidence was $8 \%$ in the $1^{\text {st }}$ step and $32 \%$ in the $2^{\text {nd }}$ step in the $1^{\text {st }}$ half. In the $2^{\text {nd }}$ half $16.22 \%$ were positive in first step and $37.84 \%$ in second step. In the 1 st half of the year in Gaderu creek, $18.52 \%$ in the $1^{\text {st }}$ step and $40.74 \%$ in the $2^{\text {nd }}$ step. In the $2^{\text {nd }}$ half $20 \%$ were positive in first step and $37.14 \%$ in second steps (Fig. 3 ).

In the 1 st half of the year (2008) at Kakinada Bay, the incidence was $20 \%$ in the $1^{\text {st }}$ step and $44 \%$ in the $2^{\text {nd }}$ step. In $2^{\text {nd }}$ half $12.12 \%$ were positive in first step and $24.24 \%$ were positive in second step. In Coringa creek in the $1^{\text {st }}$ half, $19.23 \%$ were positive in first step and $50 \%$ in second step. In $2^{\text {nd }}$ half $13.33 \%$ were positive in first step and $30 \%$ were positive in second step. At Gaderu creek in the $1^{\text {st }}$ half $17.86 \%$ were positive in first step and $42.86 \%$ were positive in second step. In the $2^{\text {nd }}$ half $14.81 \%$ were positive in first step and $29.63 \%$ were in second step (Fig. 4).

Out of the crab samples tested 16\% were positive in the first step whereas 37\% positive in the nested PCR. At Kakinada Bay, $16.4 \%$ in first step and 36\% were positive in the second step. In Coringa Creek, $14.4 \%$ and $37.3 \%$ in first step and second step respectively were positive to the disease. In Gaderu, the percentage incidence was 17.1 in first step and 37.6 in the second step (Fig.5).

\section{Size groups:-}

In 2007 at Kakinada bay, the intensity of positivity in the three different size classes $v i z ., 0-4 \mathrm{~cm}, 5-8 \mathrm{~cm}$ and $9-13 \mathrm{~cm}$ was $41.67 \%, 25 \%$ and $25 \%$ respectively. In Coringa creek, the intensity of positivity was $62.5 \%, 44.44 \%$ and $30.77 \%$ in the three different size classes $0-4 \mathrm{~cm}, 5-8 \mathrm{~cm}$ and $9-13 \mathrm{~cm}$ respectively for the year. In Gaderu, the intensity of positivity in $0-4 \mathrm{~cm}$ size was $50 \%$, in $5-8 \mathrm{~cm}$ it was $43.48 \%$ and it was $31.82 \%$ in $9-13$ size group (Fig.6).

At Kakinada Bay region, the percentage occurrence of the disease in the three different size classes $0-4 \mathrm{~cm}, 5-8 \mathrm{~cm}$ and $9-13 \mathrm{~cm}$ was $40 \%, 35 \%$ and $25 \%$ respectively in 2008. At Coringa it was $57.14 \%, 32.26 \%$ and $25 \%$ in size groups of $0-4 \mathrm{~cm}, 5-8 \mathrm{~cm}$ and $9-13 \mathrm{~cm}$ respectively. In Gaderu region the intensity of positivity was $57.14 \%$ in $0-4 \mathrm{~cm}$ size group, $28.57 \%$ in $5-8 \mathrm{~cm}$ size group and $30 \%$ in the size group of $9-13 \mathrm{~cm}$ (Fig.7).

The overall showed that at Kakinada Bay, the intensity of positivity in the three different size classes viz., $0-4 \mathrm{~cm}$, $5-8 \mathrm{~cm}$ and $9-13 \mathrm{~cm}$ was $40.84 \%, 30 \%$ and $30 \%$ respectively. In Coringa creek, it was $59.82 \%, 38.35 \%$ and $32.88 \%$ in the three different size classes. In Gaderu, the intensity of positivity in $0-4 \mathrm{~cm}$ size was $53.37 \%$, in $5-8 \mathrm{~cm}$ it was $36.02 \%$ and it was $30.91 \%$ in $9-13$ size group (Fig.8). 


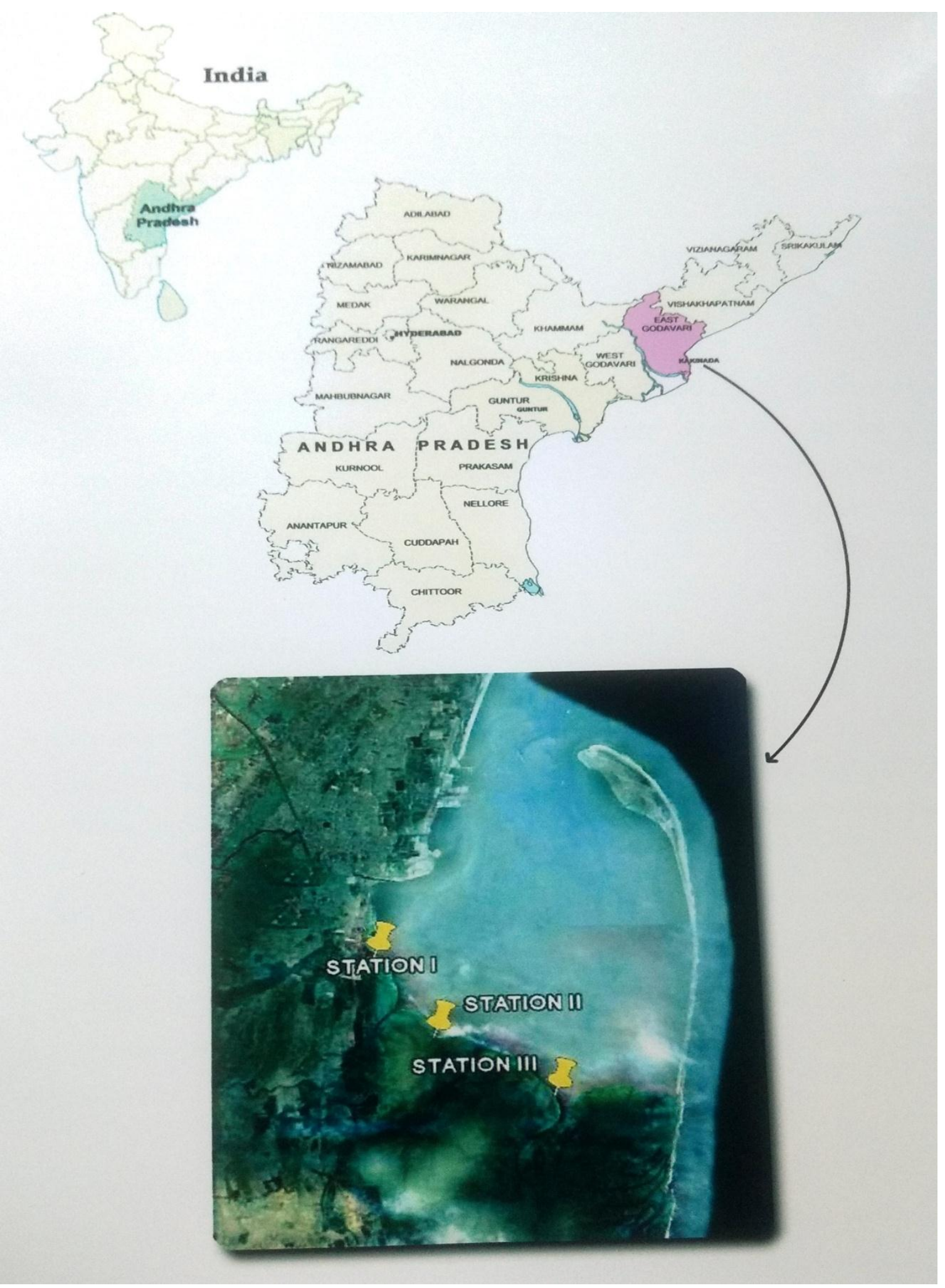

Fig1:- Study area. 




Fig2:- Electropherogram of WSSV in S. serrata of Coringa mangroves.

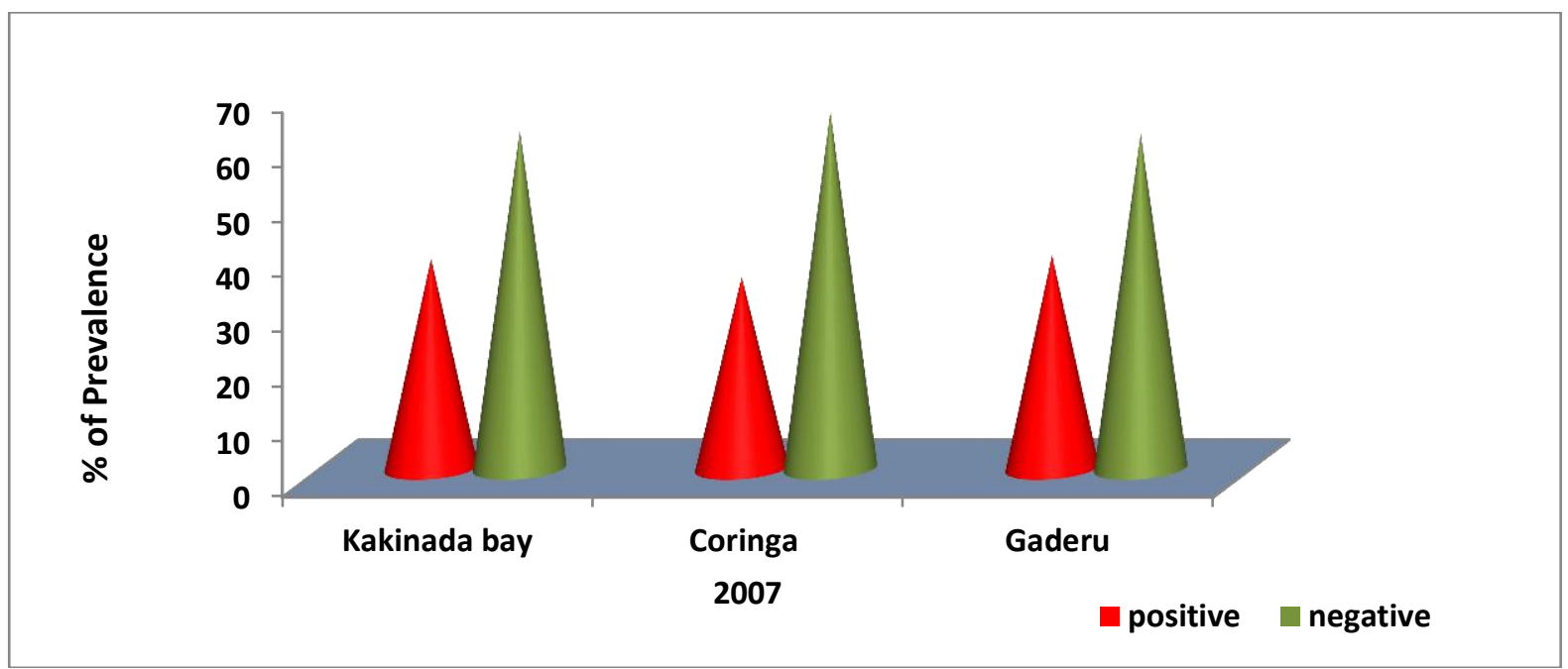

Fig. 3:-Prevalence of WSSV in S. serrata at three stations of Coringa mangroves in 2007. 


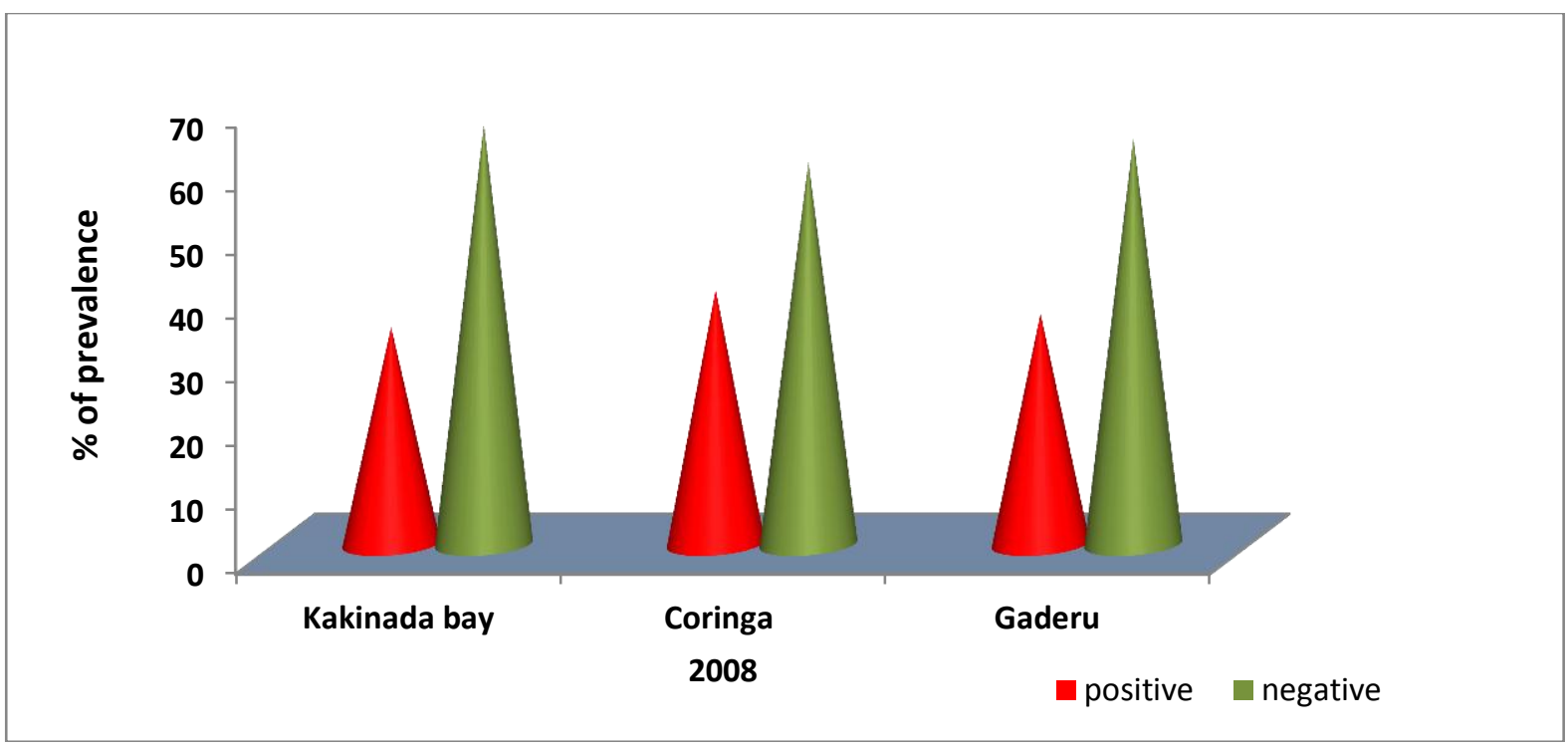

Fig. 4:-Prevalence of WSSV in S. serrata at three stations of Coringa mangroves in 2008.

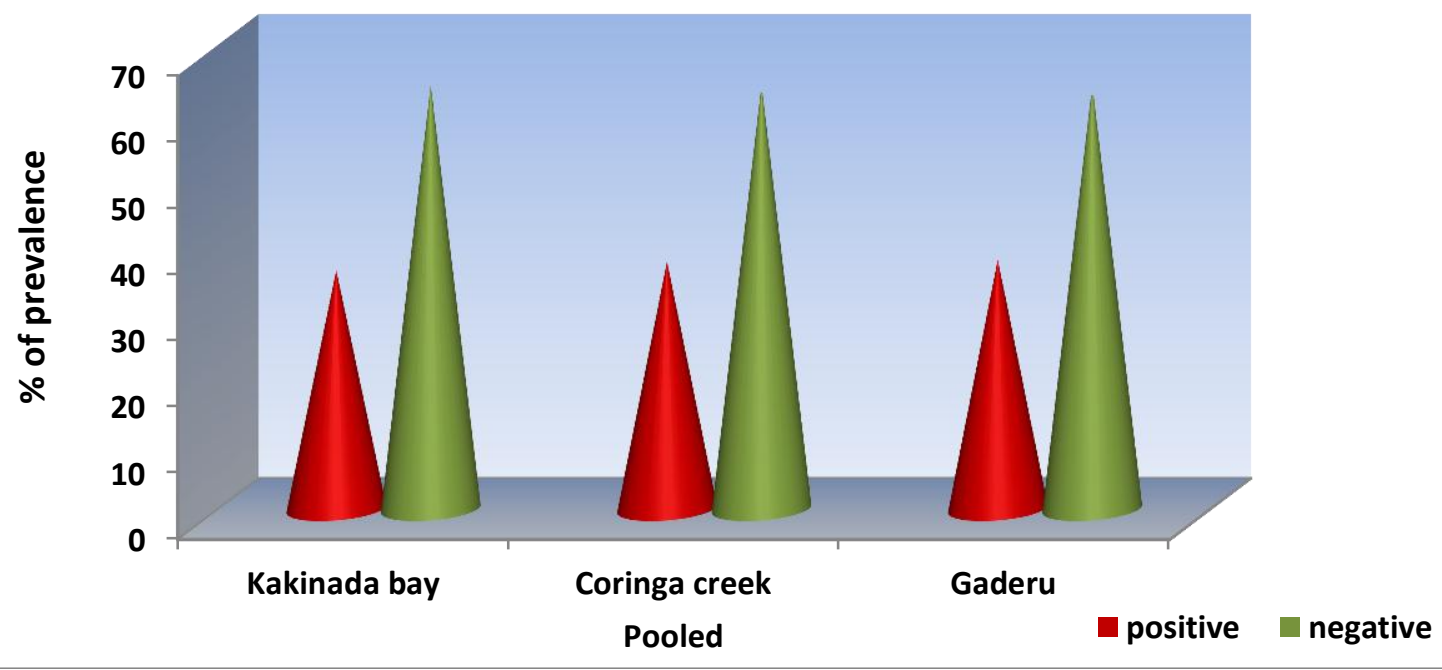

Fig. 5:-Prevalence of WSSV (Overall) in S. serrata at three stations of Coringa mangroves. 


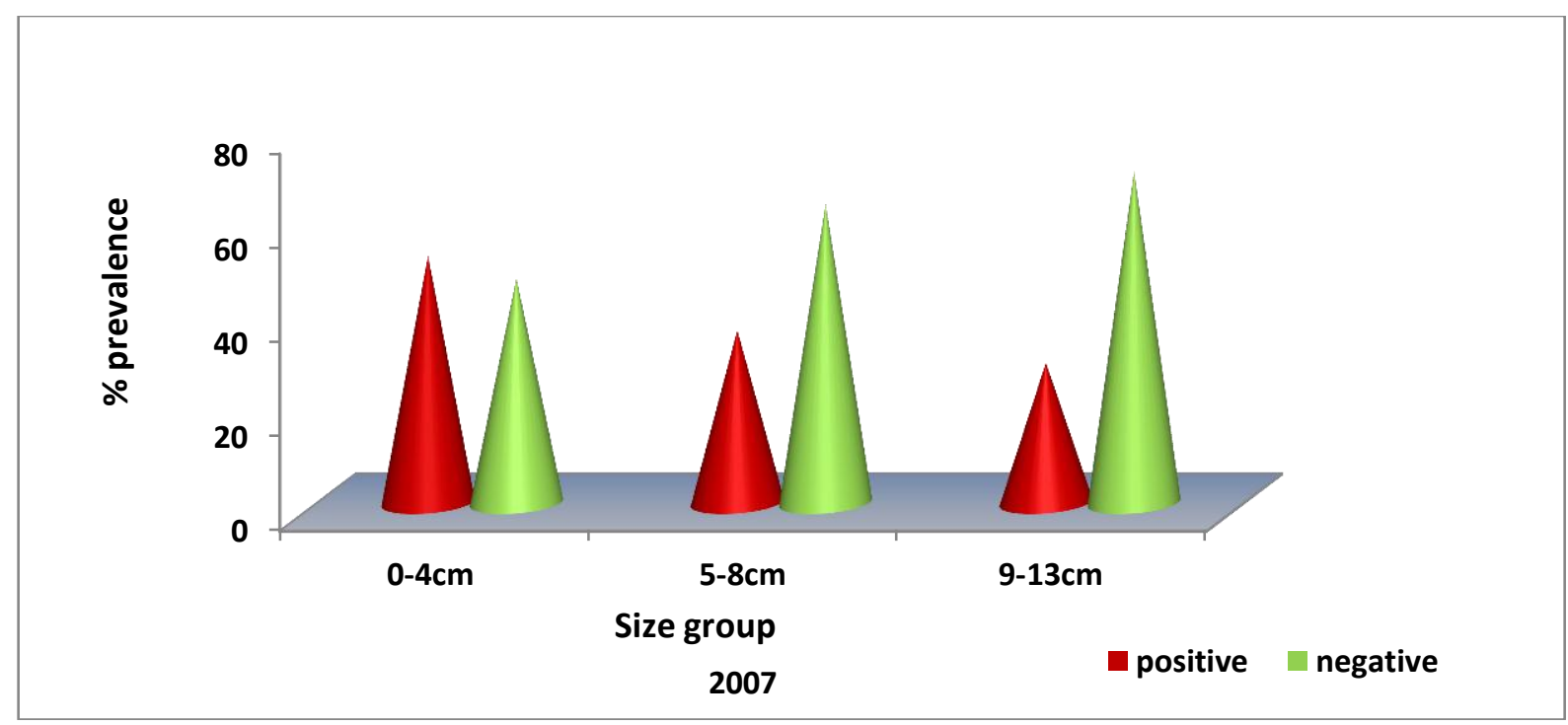

Fig. 6:-Prevalence of WSSV in different size groups of mud crab S. serrata of Coringa Mangroves in 2007.

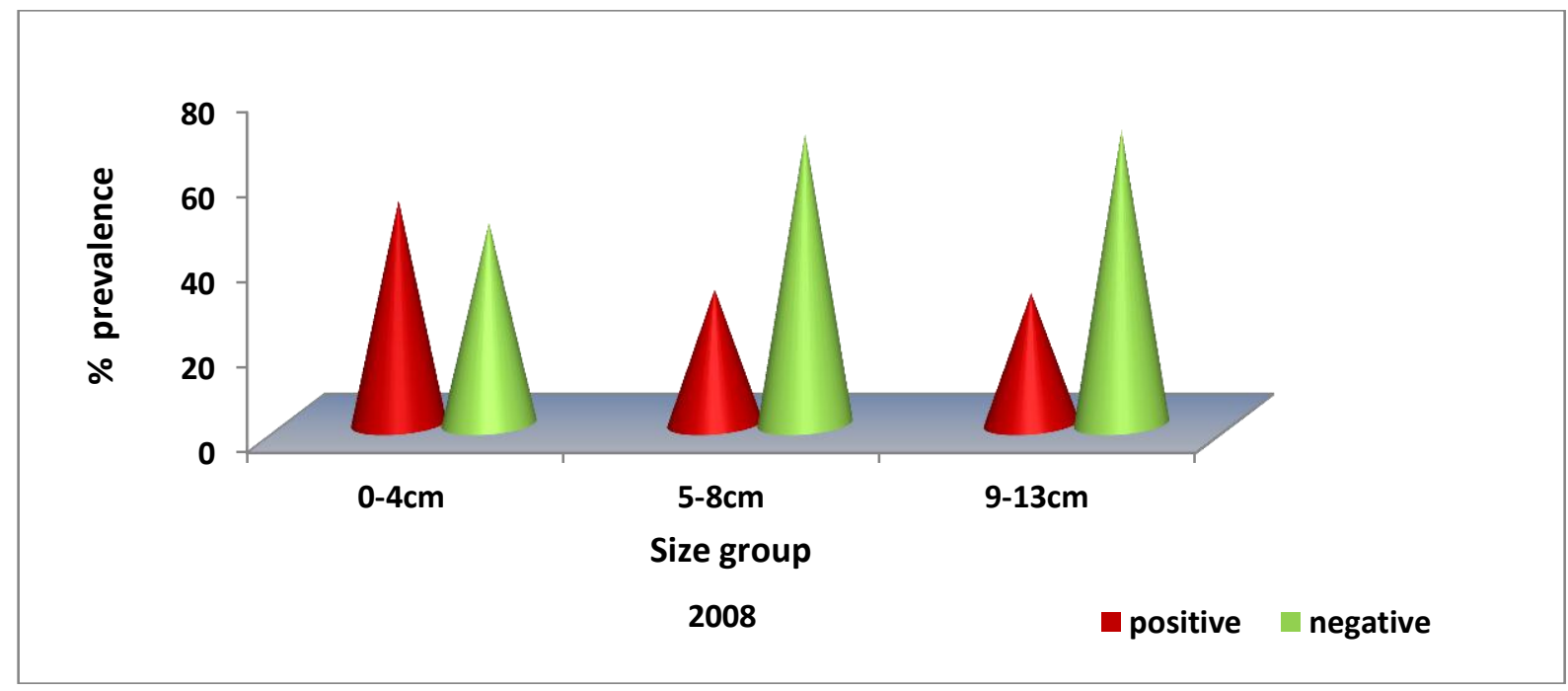

Fig. 7:-Prevalence of WSSV in different size groups of mud crab S. serrata of Coringa Mangroves in 2008. 




Fig. 8:-Prevalence of WSSV (Overall) in three size groups of mud crab S. serrata of Coringa mangroves.

\section{Discussion:-}

WSSV has become a major threat in shrimp culture causing overnight mass mortalities and there are no reports of incidence of WSSV in India before 1994. Karunasagar et al (1997) have reported severe mortalities of cultured shrimp Penaeus monodon due to WSSV. The white spot virus is believed to have been transmitted through seed and brooders brought to India from Southeast Asian countries, where the virus has been very much prevalent (Shankar and Mohan, 1998). A list of susceptible species of WSSV has been presented by Lo et al (1996). Crustaceans other than shrimps may also serve as carriers of the disease though they do not exhibit any clinical signs of WSSV externally and are also active and healthy. The mud crab S. serrata has also been found to be the same.

Mud crabs are known as carriers and vectors of WSSV (Lo et al., 1996). Natural WSSV infections have been found in captured and cultured specimens of the mud crab S. serrata in many countries of Asia (Lo et al., 1996; Kanchanaphumet al., 1998). WSSV has been detected in around $60 \%$ of the benthic larvae of mud crab, S. Serrata both under natural and experimental conditions (Chen et al., 2000). Although mud crab is known to be a carrier of WSSV in India, studies are limited. In the present study, nested PCR has been used for better sensitivity. It has also been suggested by Lo et al (1996) that the two-step PCR $10^{3}$ to $10^{4}$ times more sensitive than 1-step PCR. Kou et al (1998) have opined that the sensitivity of the 2-step amplification is $10^{3}$ to $10^{4}$ times greater than that of the 1-step amplification.

Otta et al (1999) have carried out a study to evaluate the crustaceans as potential carriers of WSSV using PCR. After the WSSV outbreaks in India during late 1994, in the shrimp culture ponds, several instances of White spots on the exoskeleton of mud crab, S. serrata have been observed. Mud crab has been shown to be a carrier of WSSV in Taiwan (Lo et al., 1996) and Thailand (Kanchanaphum et al., 1998, Supamattaya et al., 1998). Otta et al (1999) have tested one mud crab with external symptoms and 20 healthy samples without white spots and reported that the one with external symptoms is positive in the $1^{\text {st }}$ step PCR whereas 3 out of 20 healthy specimens are positive in the $2^{\text {nd }}$ step PCR indicating that $S$. serrata is also a carrier of WSSV. In India, it has been noticed that the natural prevalence of WSSV in crab is about 5.06\% while in shrimp culture ponds it is about 30\% (CIBA, 2009). In the present study the prevalence of WSSV has been found to be 37.8\% for the year 2007 and 36.09\% for 2008 .

It is evident from the present study that the samples collected from Kakinada bay region have shown that only $16.4 \%$ positive in $1^{\text {st }}$ step PCR whereas $36 \%$ are positive in $2^{\text {nd }}$ step. Coringa creek region have shown that $14.41 \%$ samples are positive PCR whereas $37.29 \%$ in $2^{\text {nd }}$ step PCR reaction. In case of Gaderu creek region, $17.1 \%$ samples are positive in $1^{\text {st }}$ step PCR and $37.61 \%$ in $2^{\text {nd }}$ step PCR. Thus this study has confirmed that nested PCR is very sensitive to viral disease diagnosis than $2^{\text {nd }}$ step PCR. 
The wild populations of mud crabs harbouring WSSV as carriers may adversely affect the shrimp production in the culture ponds, since shrimp culture ponds has been located in the vicinity of crab fishery. According to Rajendran $e t$ al (1999) S. serrata which is orally infected with WSSV has shown 10-20\% mortality in 30 days. The infected crabs have shown marked histopathological changes similar to those reported earlier for WSSV in naturally infected shrimp (Wongteerasupaya et al., 1995). Similar results have been observed by Hossain et al (2001). Chakraborty et al (2002) have reported that all the specimens of $S$. serrata collected from different localities are positive to WSSV.

The prevalence of the disease is more during wet season (June-Sep) than the dry season (Jan-June) in both years. Of the three regions, the prevalence is $36 \%$ at Kakinada Bay, $37.3 \%$ in Coringa and $37.6 \%$ in Gaderu. It may be due to the discharge of waters from shrimp ponds, containing pathogen into the creeks and drainage canals, since the shrimp culture is very high in the region (about 675 ha near Coringa and 1050 ha near Gaderu). Much difference in the percentage of positivity has also been observed in samples of different size classes. It is evident that among the three size classes $0-4 \mathrm{~cm}, 5-8 \mathrm{~cm}, 9-13 \mathrm{~cm}$, the smallest size class showed higher percentage of positivity i.e. $52.38 \%$ in 2007 and $52.63 \%$ in 2008. The same is noticed in all three areas of study. The lowest of positivity was noticed in the size class $9-13 \mathrm{~cm}$ confirming that the smaller ones are more susceptible to this virus.

\section{Acknowledgements:-}

The authors are grateful to the Head, Department of Marine Living Resources, Andhra University, Visakhapatnam for providing facilities to carry out research work.

\section{References:-}

1. Chang, P. S., Lo C. F., Wang Y. C. and Kou G. H.. (1996): Identification of white spot syndrome associated baculovirus WSBV target organs in the shrimp Penaeus monodon by in situ hybridization.Dis. Aquat. Org., 7: 131-139.

2. Chen, L. L., Lo C. F., Chiu Y. L., Chang C. F., and Kou G. H.. (2000): Natural and experimental infection of white spot syndrome virus (WSSV) in benthic larvae of mud crab Scylla serrata. Dis. Aquat. Organ.,40: 157161.

3. Chakraborty, A., Otta S. K., Joseph B., Kumar S., Shahadat Hossain Md., Karunasagar I., Venugopal M. N. and Karunasagar I. (2002): Prevalence of white spot syndrome virus in wild crustaceans along the coast of India. Current Science. 82(11): 1392-1397.

4. CIBA (Central Institute of Barckish water Aquaculture). (2009): Special publicationNo. 45 on Mud crab culture.

5. Flegel, T.W. (2001): The shrimp response to viral pathogens. In: The new wave. Browdy, C.L., Jory, D.E. (Eds). Proceedings of the special session on sustainable shrimp aquaculture, Orlando. World Aquaculture Society: 190-214.

6. Hossain, M. S., Chakraborty A., Joseph B., Otta S. K., Karunasagar I., Hossain M. S., Otta S. K.and Karunasagar I. (2001): Detection of white spot syndrome virus (WSSV) in wild captured shrimp and in noncultured crustaceans from shrimp ponds/ghers in Bangladesh by polymerase chain reaction. Fish Pathol.,36: 9395.

7. Hossain, M. S., Otta S. K., Chakraborty A., Sanath Kumar H. and Karunasagar, I. (2004): Detection of WSSV in cultured shrimps, captured brooders, shrimp postlarvae and water samples in Bangladesh by PCR using different primers. Aquaculture, 237: 59-71.

8. Kanchanaphum, P., Wongteerasupaya C., Sitidilokratana N., Boonsaeng V., Panyim S., Tassankajon. A., Withachumnarnkul. B. and Flegel. T.W. (1998): Experimental transmission of White Spot Syndrome Virus (WSSV) from crabs to shrimp Penaeus monodon. Dis. Aquat. Org., 34: 1-7.

9. Karunasasagar, I., Otta S. K. and Karunasagar I. (1997): Histopathological and bacteriological study of white spot syndrome of Penaeus monodon along the west coast of India. Aquaculture, 153: 9-13.

10. Kim, C. K., Kim P. K., Sohn S. G., Sim D. S., Park M. A., Heo M. S., Lee T. H., Lee J. D., Jun. H. K. and Jang K. L. (1998): Development of a polymerase chain reaction (PCR) procedure for the detection of baculovirus associated with white spot syndrome (WSBV) in penaeid shrimp. Journal of Fish Diseases, 21(1): 11-17.

11. Kou, G. H., Peng S. E., Chiu Y. L. and Lo C. F. . (1998): Tissue distribution of white spot syndrome virus (WSSV) in shrimp and crabs. In: Flegel, T.W. (Ed.). Advances in shrimp biotechnology. National Centre of Genetic Engineering and Biotechnology, Bangkok, pp. 267-271. 
12. Lo, C. F., Ho C. H., Peng S. E., Chen C. H., Hsu H. C., Chiu Y. L., Chang C. F., Liu K. F., Su M. S., Wang C. H. and Kou G. H. (1996): White spot syndrome baculovirus (WSBV) detected in cultured and captured shrimp, crabs and other arthropods. Dis. Aquat. Org., 27(3): 215-225.

13. Nunan, L.M., Poulos B.T. and LightnerD.V.. (1998): The details of White Spot Syndrome Virus (WSSV) and yellow head virus in imported commodity shrimp. Aquaculture, 160: 19-30.

14. E.(2003): Diagnostic manual for Aquatic animal diseases $4^{\text {th }}$ edition. Office International. Des. Epizooties , Paris, France. Pp.358.

15. Otta, S. K., Shubha G., Joseph B., Chakraborty A., Karunasagar I., and Karunasagar. (1999): Polymerase chain reaction (PCR) detection of white spot syndrome virus (WSSV) in cultured and wild crustaceans in India. Dis. Aquat. Org., 38(1): 67-70.

16. Peng, S.E., Lo C.F., Wang C. H., Ho C. H., Chang C. F. and Kou G. H. (1998): Detection of white spot baculovirus (WSBV) in giant fresh water prawn, Macrobrachium rosenbergii, using polymerase chain reaction. Aquaculture, 164: 253-262.

17. Rajendran, K.V., Vijayan K. K., Santiago T. C. and Krol R. M. (19990: Experimental host range and histopathology of white spot syndrome virus (WSSV) infection in shrimp, prawns, crabs and lobsters in India. Journal of Fish Diseases, 22: 183-191.

18. Sahul Hameed, A. S., Anilkumar M., Stephen R. M. L. and Jayaraman K. (1998): Studies on the pathogenicity of systemic ectodermal and mesodermal baculovirus and its detection in shrimp by immunologic methods. Aquaculture, 160(1-2): 31-45.

19. Sambrook, J. and Russell, D. W. (2001): Molecular cloning: A laboratory manual. Cold Spring Harbor Laboratory Press, Cold Spring Harbor, New York, 2028 pp.

20. Shankar, K.M. and Mohan C.V. (1998): Epidemiological aspects of shrimp viral diseases in India - a review. Journal of Aquaculture in the Tropics, 13(1): 43-49.

21. Supamattaya, K., Hoffmann R.W., BoonyaratpalinS.and Kanchanaphum P. (1998): Experimental transmission of white spot syndrome virus (WSSV) from black tiger shrimp Penaeus monodon to the sand crab Portunus pelagicus, mud crab Scylla serrata and krill Acetes sp. Diseases of Aquatic Organisms, 32: 79-86.

22. Takahashi, Y., Itami T., Kondao M., Maeda M., Fujii R., Tomanaga S., SupmattayaK.and Boonyartpalin. S. (1994): Electron microscopic evidence of bacilliform virus infection in kuruma shrimp (Penaeus japonicus). GyoboKenkyu, Fish Pathol., 29: 121-125.

23. Van Hulten, M. C. W., Westenberg M., Goodall S. D.andVlak J. M. (2000): Identification of two major virion protein genes of white spot syndrome virus of shrimp. Virology, 266: 227-236.

24. Wang, Y. G., Hassan M. D., Shariff M., Zamri S. M. and Chen X. (1999): Histopathology and cytopathology of white spot syndrome virus in cultured Penaeus monodon from peninsular Malaysia with emphasis on pathogenesis and the mechanism of white spot formation. Dis. Aquat. Org., 39: 1-11.

25. Wedemeyer, G. (1970): The role of stress in the disease resistance of fish. In: S. F. Snieszko (Ed.) A Symposium on Diseases of Fishes and Shellfishes. Pp 30-35. Am. Fish. Soc., Washington, DC. Spec. Publ. No. 5, Bethesda, MD.

26. Wongteeerasupaya, S., Vickers J. E., Sriurairatana S., Nash G., Akarajamorn L., Boonsaeng A., Panyim V., Tassanakajon S., Withyachumnarnkul A. and Flegel T. W. (1995): A non-occulded, systemic baculovirus that occurs in cells of ectodermal and mesodermal origin and caused high mortality in the black tiger prawnPenaeus monodon. Dis. Aquat. Org., 21: 69-77.

27. Wongteerasupaya, C., Wongwisansri S., Boonsaeng V., Panyim S., Withyachumnarnkul B., and Flegel T. W. (1996): Sensitive and rapid detection of systemic ectodermal and mesodermal baculovirus by DNA amplification. World Aquaculture '96, Book of Abstracts, World Aquaculture Society, Baton Rouge, LA. p. 443. 